\title{
Effect of grazing, spraying, and seeding on knapweed in British Columbia
}

\author{
JAMES F. MAXWELL, ROBERT DRINKWATER, DAVID CLARK, AND JOHN W. \\ HALL
}

\begin{abstract}
Authors are regional manager, Public Lands Division, Drayton Valley, Alberta; district agriculturist, Ministry of Agriculture and Fisheries, Creston, British Columbia; plant ecologist, Ministry of Environment, Victoria British Columbia; statistician, Agriculture Canada Research Station, Vancouver, British Columbia.
\end{abstract}

\begin{abstract}
The effects of late fall grazing, application of picloram ( 4 amino3,5,6-trichloro-2-pyridinecarboxylic acid), and seeding on the reinfestation by knapweed (Centaurea diffusa Lam.) were investigated on a knapweed-infested grassland range in southern British Columbia. The seeding treatments were an unseeded control, crested wheatgrass (Agropyron cristatum L.), Russian wildrye (Psathyrostachys junceus (Fisch.)Nevski)), 'Drylander' alfalfa (Medicago sativa $L_{\text {.), }}$ and a rangeland seed mix. The spraying treatment was applied ( $0.56 \mathrm{~kg}$ a.i. per ha.) to only the unseeded control, Russian wildrye, and crested wheatgrass treatments. Reestablishment of knapweed and establishment of seeded and indigenous species were observed over 4 years. Knapweed cover never exceeded $10 \%$ on sprayed plots but ranged from $35 \%$ to $60 \%$ on unsprayed plots. Knapweed cover was greater on unsprayed grazed plots and re-establishment was more rapid on sprayed grazed plots than on ungrazed ones. Seeding produced little difference in knapweed cover but crested wheatgrass and rangeland mix (which contained crested wheatgrass) had the lowest coverage of knapweed on unsprayed plots. Russian wildrye did not establish and this failure plus the disturbance created by seeding provided ideal conditions for a surge of knapweed growth. No differences in knapweed cover were detected among seeding treatments on sprayed plots. It is concluded that spraying is far more important than seeding for controlling knapweed, and grazing pressure must be carefully controlled to prolong the effects of treatment.
\end{abstract}

Key Words: Centaurea diffusa, picloram, weed control, alfalfa, crested wheatgrass, Russian wildrye

Since their introduction to British Columbia in the late 1800 s the knapweeds (Centaurea spp.), particularly diffuse ( $C$. diffusa Lam.) and spotted knapweed ( $C$. maculosa Lam.) have invaded vast areas of grassland and open forested rangelands. By 1972 the infestation, estimated at $30,000 \mathrm{ha}$, was negatively affecting all users of the range resource including recreationists, wildlife, and cattle ranchers (Harris and Cranston 1979). Presently the grassland and many of the open forest rangelands in the Boundary Forest District are infested to some degree with knapweed. A coordinated effort has been under way since the 1970 s to contain the knapweed infestation and prevent further losses. Included in these efforts are attempts to reclaim or rehabilitate critical rangelands that have become infested.

When infestation by knapweeds occurs forage production losses are usually severe and often rehabilitation of rangelands is essential

\footnotetext{
Authors wish to thank Laila Salm for assistance in data collection, and E. Hogue for assistance with experimental design.

Research was conducted while Mssrs. Maxwell, Drinkwater, and Clark were employed by the British Columbia Ministry of Forests. Funding was provided by Ministry of Forests, Nelson Forest Region.

Manuscript accepted 25 July 1991.
}

for the continued operation of a cattle ranch or maintenance of critical wildlife habitat. Rehabilitation methods have included cultivating, seeding, and irrigating arable land or using herbicides such as 4 amino-3,5,6-trichloro-2-pyridinecarboxylic acid (picloram) on rugged rangelands. Seeding of dryland grass and legume species is often done independently or in conjunction with herbicide treatment. Rehabilitation objectives include changing the vegetation to a more preferred mix and preventing re-infestation by knapweed for as long as possible.

Certain treatments including the seeding of certain species may have been more effective than others in rehabilitating sites and preventing or suppressing invasion by knapweeds (Berube and Myers 1982). Management, particularly grazing management of cattle, may also affect the degree and length of knapweed control, although studies of the effect of grazing have not been reported. The objective of this study was to assess the independent and combined impacts of seeding, spraying, and grazing treatments on knapweed cover on an important grassland range in the Boundary Forest District.

\section{Materials and Methods}

The study was conducted on a Crown-owned grassland range east of Grand Forks, British Columbia (latitude 4905 , longitude 118 17). Elevation is $550 \mathrm{~m} \mathrm{ASL}$, and there is a slight south aspect. The site is within the dry, hot subzone of the Ponderosa Pine Bunchgrass biogeoclimatic zone (Farley 1979). Soils on the site are Republic gravelly sandy loam, and are in the Orthic Black subgroup. They are moderately well to rapidly drained (Sprout and Kelly 1964). Average precipitation is $447 \mathrm{~mm}$, with $324 \mathrm{~mm}$ falling as rain, and the remainder as snow.

The area is heavily infested with diffuse knapweed. Undisturbed native range is dominated by: diffuse knapweed, 30-60\% cover; Kentucky bluegrass (Poa pratensis L.), 10-20\% cover; needlegrasses (Stipa spp.), 10-15\% cover; and cheatgrass (Bromus tectorum L.), 0-20\% cover.

The study was conducted in 2 adjacent areas, 1 on each side of Highway 3. The area to the north of the highway was grazed annually by cattle from 1 Sept. to 30 Nov. at a stocking rate of 4.5 ha/AUM; the area to the south of the highway was ungrazed. The area also supports large numbers of mule and whitetail deer (Odocoileus hemionus hemionus Raf. and Odocoileus virginianus ochrourus Bailey, respectively).

Each of the 2 study areas covered 0.3 ha, and was divided into 4 blocks. Each block consisted of 5 plots of $5 \mathrm{~m} \times 30 \mathrm{~m}$, each of which was further subdivided into 2 equal-sized sub-plots. Each seeding and spraying treatment was applied once in each block. Randomization was carried out in assigning the 5 seeding treatments to main plots and the 2 herbicide treatments (sprayed, unsprayed) to sub-plots. 
A picloram spray (4 amino-3,5,6, trichloro-2-pyridinecarboxylic acid) was applied on 10 May 1984 by handgun at the rate of $0.56 \mathrm{~kg}$ active ingredient per hectare. Weather conditions at the time of application were clear and warm with winds of $5-8 \mathrm{~km}$ per hour. Plots that were to be seeded to alfalfa or rangeland mix were not sprayed as the herbicide is phytotoxic to the legume component.

Seeding operations were conducted 4 Oct. 1984. Prior to seeding, old vegetation was removed using a tractor-mounted rotary mower. The seedbed was prepared using a rotovator mounted on a 72 horsepower tractor. Plots were broadcast-seeded at approximately $30 \mathrm{~kg}$ per ha, and rolled with a water-filled drum roller.

Seeding treatments were as follows: (1) Crested wheatgrass (Agropyron cristatum L.); (2) Russian wildrye (Psathyrostachys junceus (Fish)Nevski)); (3) 'Drylander' alfalfa (Medicago sativa L.); (4) Rangeland seed mix: $12.5 \%$ white sweetclover (Melilotus alba Medic.), $12.5 \%$ 'rambler' alfalfa, $12.5 \%$ intermediate wheatgrass ( $A$. intermedium Host), 25\% smooth brome (Bromus inermis Leyss.), and $37.5 \%$ crested wheatgrass; and (5) unseeded (control).

Foliar cover of all vegetation was measured during early July in 1985,1986 , and 1988. In each plot, a permanent $10-\mathrm{m}$ transect was established with stations at $1-\mathrm{m}$ intervals. Foliar cover for each species was recorded using a 6-point 'Daubenmire' scale and measured using a $15 \mathrm{~cm} \times 30-\mathrm{cm}$ plot frame placed at the stations (Daubenmire 1959). The same transects and stations were monitored in each year of data collection.

Statistically, the experiment was a $2 \times 5 \times 2$ factorial ( 2 grazing, 5 seeded, and 2 herbicide treatments) with 4 combinations missing (the unsprayed legume plots). Within grazing treatment, design was a randomized complete block with split plots. The 5 seeding treatments were in the main plots, and herbicide treatment in sub-plots. For each year and plot, the average percent foliar cover of each species was determined using the midpoints of the cover range scale. Analysis of variance for repeated measures in time was performed using the SAS program GLM (SAS 1985). The raw data were not transformed prior to analyses as variances were homogeneous. Time was analyzed using the polynomial option. Differences among seeding treatments were examined using Duncan's new multiple range test at the 0.05 significance level.

\section{Results and Discussion}

Changes in foliar cover are reported only for knapweed and the primary forage species on the site, namely the species present in the seed mixtures and the indigenous forage grasses (cheatgrass, Kentucky bluegrass, and needlegrass). Other species were observed too sporadically to be amenable to analysis or were not considered to be important forages.

\section{Knapweed}

Cover of knapweed was greatly reduced by the application of picloram (Table 1). Coverage ranged from $35 \%$ to more than $60 \%$ on unsprayed plots but never exceeded $10 \%$ on sprayed plots. This difference in knapweed cover resulted in a significant $(p<0.01)$ 3-way interaction among years, seeding, and spraying and was reflected in a different variance for the sprayed and unsprayed plots. In order to understand the relationships involved, and to account for the different variances, additional statistical analyses were carried out separately for the data from the sprayed and unsprayed treatments.

When no picloram was applied, there was more knapweed on grazed than on ungrazed plots $(p<0.05)$. This difference did not change over time and may reflect the effect of grazing prior to the initiation of the experiment. After spraying, there was a year by grazing interaction $(p<0.01)$ with knapweed re-establishing more rapidly on grazed than on ungrazed plots (Table 1 ). This finding is surprising in light of the fact that grazing occurred only late in the growing season. Although the grazed and ungrazed areas were
Table 1. Effect of picloram and grazing on average foliar cover (\%) of knapweed at Grand Forks. B.C.

\begin{tabular}{|c|c|c|c|c|}
\hline \multirow[b]{2}{*}{ Picloram } & \multirow[b]{2}{*}{ Grazing } & \multicolumn{3}{|c|}{ Year } \\
\hline & & 1985 & 1986 & 1988 \\
\hline \multicolumn{4}{|c|}{ A. Control (native range) plots } & \\
\hline No & Yes & 65.5 & 52.6 & 59.4 \\
\hline No & No & 51.9 & 29.1 & 32.8 \\
\hline Yes & Yes & 5.9 & 4.5 & 6.4 \\
\hline & No & 0.0 & 0.9 & 0.0 \\
\hline \multicolumn{5}{|c|}{ Standard errors: unsprayed 7.92 sprayed 3.08} \\
\hline \multicolumn{5}{|c|}{ B. All plots } \\
\hline No & Yes & 52.3 & 55.1 & 57.2 \\
\hline No & No & 36.2 & 43.6 & 39.5 \\
\hline Yes & Yes & 0.4 & 2.7 & 8.4 \\
\hline Yes & No & 0.4 & 0.8 & 0.3 \\
\hline \multicolumn{5}{|c|}{ Standard errors: unsprayed 3.54 sprayed 1.38} \\
\hline
\end{tabular}

separated only by a road, all the differences attributed to grazing must be viewed with caution until they can be demonstrated in a variety of locations. If these results are confirmed, it is anticipated that grazing effects will be more dramatic on sites where grazing occurs earlier in the growing season, or where grazing pressure is greater.

When no picloram was applied, there was an interaction between seeding and years $(p<0.01)$ though the pattern was unclear (Table 2). Crested wheatgrass and rangeland mix (which

Table 2. Effect of picloram and seeding on average foliar cover (\%) of knapweed at Grand Forks, B.C.

\begin{tabular}{|c|c|c|c|}
\hline \multirow[b]{2}{*}{ Treatment } & \multicolumn{3}{|c|}{ Year } \\
\hline & 19851 & 1986 & 1988 \\
\hline $\begin{array}{l}\text { A. Unsprayed plots } \\
\text { Native range } \\
\text { Alfalfa } \\
\text { Russian wildrye } \\
\text { Crested wheatgrass } \\
\text { Rangeland mix } \\
\text { Standard error }\end{array}$ & $\begin{array}{l}58.7 \mathrm{a} \\
46.2 \mathrm{ab} \\
45.6 \mathrm{ab} \\
35.7 \mathrm{~b} \\
35.0 \mathrm{~b} \\
5.59\end{array}$ & $\begin{array}{l}--\%-- \\
40.8 \mathrm{~b} \\
54.8 \mathrm{ab} \\
62.0 \mathrm{a} \\
38.1 \mathrm{~b} \\
51.1 \mathrm{ab}\end{array}$ & $\begin{array}{l}46.1 \mathrm{ab} \\
52.1 \mathrm{ab} \\
61.9 \mathrm{a} \\
38.5 \mathrm{~b} \\
43.3 \mathrm{ab}\end{array}$ \\
\hline $\begin{array}{l}\text { B. Sprayed plots } \\
\text { Native range } \\
\text { Russian wildrye } \\
\text { Crested wheatgrass } \\
\text { Standard error }\end{array}$ & $\begin{array}{c}0.0 \mathrm{a} \\
0.5 \mathrm{a} \\
0.7 \mathrm{a} \\
1.69\end{array}$ & $\begin{array}{l}2.4 a \\
1.9 a \\
0.9 a\end{array}$ & $\begin{array}{l}7.0 \mathrm{a} \\
2.9 \mathrm{a} \\
3.3 \mathrm{a}\end{array}$ \\
\hline
\end{tabular}

'Within year and herbicide treatment means followed by same letter are not significantly different at the 0.05 level.

contained crested wheatgrass) tended to have the lowest knapweed cover. After 4 years, Russian wildrye, which had still not established, had a significantly greater coverage of knapweed than crested wheatgrass alone. The lack of establishment by the Russian wildrye, combined with the disturbance created by seeding, provided ideal conditions for a surge of knapweed growth. After spraying, there were no differences in knapweed cover among seeding treatments or interactions of seeding with years or grazing. These observations are consistent with those of Berube and Myers (1982) who found that 9 years after seeding, the knapweed density was greater in an area seeded to Russian wildrye than in an area seeded to crested wheatgrass.

It was apparent from these results that seeding of these sites without the added benefit of an application of herbicide did not effectively reduce the knapweed population. Even the most competitive species, crested wheatgrass, when seeded without herbicide spraying resulted in a knapweed cover approaching that of 
Table 3. Effect of picioram and seeding on average foliar cover (\%) of 3 indigenous species at Grand Forks, B.C.

\begin{tabular}{|c|c|c|c|c|c|c|c|c|c|}
\hline \multirow[b]{2}{*}{ Treatment } & \multicolumn{3}{|c|}{ Cheatgrass $^{1}$} & \multicolumn{3}{|c|}{ Kentucky bluegrass } & \multicolumn{3}{|c|}{ Needlegrass } \\
\hline & 1985 & 1986 & 1988 & 1985 & 1986 & 1988 & 1985 & 1986 & 1988 \\
\hline $\begin{array}{l}\text { A. Unsprayed } \\
\text { Native range } \\
\text { Alfalfa } \\
\text { Russian wildrye } \\
\text { Crested wheatgrass } \\
\text { Rangeland mix }\end{array}$ & $\begin{array}{l}0.7 \mathrm{~b} \\
5.8 \mathrm{ab} \\
3.6 \mathrm{ab} \\
2.6 \mathrm{ab} \\
8.8 \mathrm{ab}\end{array}$ & $\begin{array}{r}3.2 \mathrm{~b} \\
14.7 \mathrm{~b} \\
4.3 \mathrm{~b} \\
2.7 \mathrm{~b} \\
9.1 \mathrm{~b}\end{array}$ & $\begin{array}{l}14.5 \mathrm{~cd} \\
18.3 \mathrm{~cd} \\
25.8 \mathrm{bc} \\
8.9 \mathrm{~d} \\
16.9 \mathrm{~cd}\end{array}$ & $\begin{array}{l}15.1 \mathrm{~b} \\
3.3 \mathrm{~b} \\
4.7 \mathrm{~b} \\
4.3 \mathrm{~b} \\
2.7 \mathrm{~b}\end{array}$ & $\begin{array}{r}--\% \\
10.7 \mathrm{a} \\
4.4 \mathrm{a} \\
3.1 \mathrm{a} \\
4.6 \mathrm{a} \\
5.4 \mathrm{a}\end{array}$ & $\begin{array}{r}12.3 \mathrm{~b} \\
6.6 \mathrm{~b} \\
3.4 \mathrm{c} \\
2.6 \mathrm{~b} \\
2.1 \mathrm{~b}\end{array}$ & $\begin{array}{l}10.8 \mathrm{bc} \\
2.5 \mathrm{c} \\
5.2 \mathrm{bc} \\
1.3 \mathrm{c} \\
2.7 \mathrm{c}\end{array}$ & $\begin{array}{l}11.1 \mathrm{~b} \\
4.4 \mathrm{~b} \\
2.9 \mathrm{~b} \\
3.7 \mathrm{~b} \\
6.4 \mathrm{~b}\end{array}$ & $\begin{array}{r}12.3 \mathrm{~b} \\
2.5 \mathrm{~b} \\
3.3 \mathrm{~b} \\
1.1 \mathrm{~b} \\
5.1 \mathrm{~b}\end{array}$ \\
\hline $\begin{array}{l}\text { B. Sprayed } \\
\text { Native range } \\
\text { Russian wildrye } \\
\text { Crested wheatgrass } \\
\text { Standard error }\end{array}$ & $\begin{array}{c}3.7 \mathrm{ab} \\
15.4 \mathrm{a} \\
3.5 \mathrm{ab}\end{array}$ & $\begin{array}{c}12.7 \mathrm{~b} \\
31.8 \mathrm{a} \\
11.3 \mathrm{~b} \\
4.25\end{array}$ & $\begin{array}{l}35.2 \mathrm{~b} \\
50.5 \mathrm{a} \\
16.2 \mathrm{~cd}\end{array}$ & $\begin{array}{r}31.2 \mathrm{a} \\
3.7 \mathrm{~b} \\
3.3 \mathrm{~b}\end{array}$ & $\begin{array}{c}20.3 \mathrm{a} \\
11.3 \mathrm{a} \\
7.8 \mathrm{a} \\
5.35\end{array}$ & $\begin{array}{r}28.1 \mathrm{a} \\
11.5 \mathrm{~b} \\
3.3 \mathrm{~b}\end{array}$ & $\begin{array}{c}34.4 \mathrm{a} \\
18.2 \mathrm{~b} \\
4.8 \mathrm{bc}\end{array}$ & $\begin{array}{c}37.9 \mathrm{a} \\
27.9 \mathrm{a} \\
6.5 \mathrm{~b} \\
4.87\end{array}$ & $\begin{array}{r}38.6 \mathrm{a} \\
29.1 \mathrm{a} \\
2.4 \mathrm{~b}\end{array}$ \\
\hline
\end{tabular}

'For each species and year, means followed by same letter are not significantly different at the 0.05 level.

untreated control. The disturbance created by seeding when not accompanied by spraying provided ideal conditions for the reestablishment of high levels of knapweed cover, particularly where species were seeded that did not provide rapid establishment of competitive vegetation.

\section{Seeded Species}

When crested wheatgrass was seeded alone, it established well and its coverage increased over the time of the study. After spraying picloram, crested wheatgrass provided, on average, a $58.1 \%$ coverage while without picloram the coverage was $30.0 \%$ (SE $2.68 \%$ ). The coverage of crested wheatgrass was $12 \%$ higher when the land was grazed than when it was ungrazed. There were no significant interactions among years after seeding, grazing, and spraying. Crested wheatgrass provided an average of $10 \%$ coverage (SE 2.68\%) on plots seeded with rangeland mix, with no significant difference between grazed and ungrazed areas.

Alfalfa was present in the rangeland mix as well as being seeded alone. It produced an average cover of $1.4 \%$ in the plots seeded to rangeland mix and $3.5 \%$ (SE 2.3\%) in the alfalfa-seeded plots. Alfalfa cover never exceeded $15 \%$ on any plot and there was no significant relationship with grazing and time after seeding.

Smooth brome provided $17 \%$ of the total number of seeds in the rangeland mix and intermediate wheatgrass contributed $7 \%$. However, smooth brome provided an average cover of $5.7 \%$ (SE 1.5\%) and intermediate wheatgrass provided an average of $3.4 \%$ (SE $1.4 \%$ ). No coverage of more than $10 \%$ was observed in any plot for either of these species. Intermediate wheatgrass coverage was unrelated to grazing or time after planting. A significant time by grazing interaction was observed for smooth brome. This was accounted for by an unusually high response of $8.5 \%$ in grazed areas in 1988 but little difference between grazed and ungrazed areas in the earlier years. The reason for this single high value is unclear.

Russian wildrye did not establish on any of the plots to which it was seeded. The greatest observed cover was $10 \%$ within 1 individual plot frame. In 1985, a few seedlings were discovered on sprayed plots but these showed epinasty, suggesting herbicide damage. However, there was no significant establishment even on unsprayed plots.

\section{Indigenous Species}

The cover of cheatgrass varied substantially over the period of the study. There were significant interactions $(p<0.01)$ of grazing, seeding, and spraying with time after initial treatment. The coverage of cheatgrass increased over time but was consistently twice as high in grazed as in ungrazed areas. Coverage was higher in sprayed than in unsprayed plots. By 1988, the greatest coverage was achieved in sprayed plots which were either unseeded or seeded with Russian wildrye (Table 3). These were the plots which had been disturbed but in which competitive species had not established.
Kentucky bluegrass is a dominant species on this site. This is common on ranges in this area which have been grazed heavily in the past. There were no significant interactions for this species and no detectable effects of grazing and spraying. There were significant differences among the seeding treatments. In 1985 and 1988, the cover of Kentucky bluegrass was higher on native range plots which had been sprayed with picloram than after other seeding treatments (Table 3).

Cover of needlegrass did not change significantly over time, but was affected by grazing, seeding, and spraying, with statistically significant interactions between spraying and grazing and between spraying and seeding. Average coverages after spraying were $31.6 \%$ and $12.8 \%$ (SE 2.5\%) on grazed and ungrazed land, respectively, while without spraying the coverages were $5.9 \%$ and $4.1 \%$ (SE 1.9\%), respectively. By 1986 the coverage of needlegrass was higher in sprayed areas seeded to Russian wildrye or left as native range than after other seeding treatments (Table 3 ). No differences were detected among the remaining seeding treatments.

\section{Management Implications}

After spraying on native range, the combined cover of desirable forages, in particular Kentucky bluegrass and needlegrasses, was approximately $65 \%$. After spraying and seeding to crested wheatgrass, the combined coverage of crested wheatgrass, Kentucky bluegrass, and needlegrass was approximately the same. Therefore, it is concluded from this study that little apparent advantage was achieved by seeding, either alone or in combination with spraying, and that spraying appears to have been the most effective treatment for reducing the cover of knapweed and increasing the cover of desirable forage species. Since this experiment was carried out in a single location, the conclusions must be viewed with caution. Further experimentation will be required in other locations to establish whether the results obtained here are of wide application.

\section{Literature Cited}

Berube, D.E., and J.H. Myers. 1982. Suppression of knapweed invasion by crested wheatgrass in the dry interior of British Columbia. J. Range Manage. 35:459-461.

Daubenmire, R. 1959. A canopy-coverage method of vegetation analysis. Northwest Sci. 33:43-66.

Farley, A.L. 1979. Atlas of British Columbia. Univ. British Col. Press, Vancouver.

Harris, P., and R. Cranston. 1979. An economic evaluation of control methods for diffuse and spotted knapweed in Western Canada. Can. J. Plant Sci. 59:375-382.

SAS Institute Inc. 1985. SAS user's guide: Statistics, Version 5 Edition. SAS Institute Inc. Cary, N.C.

Sprout, P.N., and C.C. Kelly. 1964. Soil survey of the Kettle River Valley in the Boundary District of British Columbia. Report \#9, British Columbia Soil Survey. British Columbia Dep. Agr. and Res. Brit., Can. Dep. Agr. 